\title{
The Concept of "A Literary Hero" in English and Uzbek Historical Novels
}

\author{
UmarovaMakhliyoYunusovna ${ }^{1}$ \\ DoctorResearcher, associate professor of Uzbekistan State World Languages University. ${ }^{1}$
}

\begin{abstract}
The article is devoted to the study of comparative analysis of the concept of "literary hero" in English and Uzbek historical novels based on Walter Scott's novel "Ivanhoe"and AbdullaKadiriy's novel "Bygone Days".

Literary hero is often used the concepts "character", "personage", "image", "type" and "acting person". Sometimes they are differentiated: literary heroes are called characters, drawn more multifaceted and more significant for the work's idea. The concept of "literary hero" refers only to actors close to the author's ideal of a person (the so-called hero) or embodying a heroic principle (for example, heroes of epics, epics, and tragedies). However, it should be noted that literary criticism of these concepts, along with the concepts of "character", "type" and "image" are interchangeable.

The novelty of the research is to clarify the history expressed in the first English historical novel "Ivanhoe" and first Uzbek historical novel "Bygone days" with the expressiveness of "a literary hero' in them. There are some varieties in describing the literary heroes of different country writers. In our article, we gave some features of English and Uzbek writers in describing "literary hero".
\end{abstract}

KEY WORDS: literary hero, first historical novel, creator, humanity, spiritual, concept of "literary hero", socio-political problems, English and Uzbek novels.

Article Received: 16th October, 2020; Article Revised: 30th December, 2020; Article Accepted: 08th January, 2021

\section{INTRODUCTION}

A good book is like a good man. We know; the good deeds of a good character remembered in the memory of readers. The name of a good man applies to humanity in general, to the West and to the East. The discoveries and good deeds of a good man travel the world. It takes place in the pages of history. Revered books adorn the history of spirituality. The seed of goodness sprouts and blossoms and bears fruit in the pure heart. Views expand; paths of purity, righteousness, spiritual uplift are opened. [17]

In the artistic works the author's worldview, attitude to social life, goals and objectives, philosophical approach are expressed in the image of literary heroes. Uzbek literary scholar Erkin Khudoyberdiev writes: "From ancient times, that is, from the primitive social system, events and individuals have been imitated. In the later development of literature, the type of individuals who embodied the distinctive features of certain classes, groups, and social orientations began to appear brighter and fuller"[12.40].The image of man in art and literature was originally portrayed in connection with divine powers and gods. Uzbek heroes of our epic and ancient fairy tales as "Bilgamish","Alpomish", "GurO'g'li" (Son of the grave) in are also images with divine power. AbdullaKadiriy in his pamphlet "The difficulties of creativity" stated: "it is well known that our people are still nourished by medieval epics and stories"[9.12].In the West Greco-Roman works of art worshiped gods such as Zeus, Apollo, Athena, Aphrodite, Dionysus, Ares, and Poseidon[4.12].Legends were created about them and virtues such as good and evil were sung in them. The heroes of the works of Homer the Great and the ancient Greek tragedies (Rometey, Achilles, Hector, Odysseus, Oedipus, Antigone) embodied the views and feelings of the Greek people of that time[13.250].People believed them and admired their divine 
power and magic. It is obvious that from ancient time no matter what kind of art work of mankind has done, a hero has been created and human qualities have been sung.

According to the Russian scholar Ginzburg, a literary hero is a series of references to a person in a given text. In the fictional text, the protagonist can be portrayed in a variety of ways, such as being remembered by other protagonists in conversations, analyzing the protagonist's character, as well as his or her experiences, thoughts, speeches, appearance, and the character of the author or narrator on stage. can be remembered in related events[6.89].Indeed, the protagonist can not only participate in the writtenwork himself, but can be talked about by another protagonist throughout the work. The literary hero of each period provides information about the environment, social life and the nation. What is happening around him is based on the details of history and time. According to Russian scholar Belinsky: "The spirit of the nation to which the writer belongs belongs to this nation. Describing the environment, the situation is not a separate goal, because the main character moves and lives in one environment, conditions. Moreover, the writer did not set himself the task of reflecting customs, he is not an ethnographer, he reflects life, not ethnography. The poetry of each nation reflects the character (place) and spirit (people) of the country"[3.234].

\section{MAIN PART}

As for literature, without a doubt, we are talking about any event written on paper, about the people who participated in it, from taste to amazement, horror, pleasure or shouting. All the same "Great character" in a work is a bright sign of a great work of art[16].Because a work of art is based on a hero. The main theme of a work of art is the person through whom literature fulfills its sacred duty through the artistic portrayal of characters and
types[13.250].In fact, all the details of the work take place around the person. The main characters of the work are also people who read works of art and draw conclusions from them, even if they are images of animals.In literary criticism, terms such as "image", "character" and "type" are harmoniously combined with the concept of a literary hero. The first information about the image can be found in "On the Art of Poetry" by Aristotle in the form of "mimesis".The scholar believed that he created the image as an imitation of marriage. Later, the German philosopher Hegel, in his aesthetic work reflected on art and said that "art thinks in images."

In Russian terminology until the beginning of the twentieth century, instead of the term "image," terms as "emblem", "description", "copy" were used. The term "image" entered the Uzbek terminology in the 20-30s of the twentieth century[12.51]. These terms complete each other and are widely used in the analysis of a work of art.

According to the literary critic Tokhta Boboev's idea, an "image" is a description of the life of all people involved in a work (the plot of a work means various "carriers" - the main character, protagonist, episodic image).A literary type is a character that can be a great generalization of the period, representing important features of a social group or class, if the plot of the work is characterized only by individuals who differ in the direction of will and individual mental characteristics. In oral and written language, the terms "character" and "image" can also be used interchangeably [2.51].Consequently, the vivid expression of a person, which manifests itself in social conditions by his individual actions and emotional experiences, is called character.

Another literary critic, Mateokub Kushchanov, described the "character" as an image that sharply differs from others in terms of subject matter, willpower and individual characteristics $[11.12,10.16]$. In 
this regard, the Oxford Dictionary of English Scholars defines a "hero" as follows: "A hero is the protagonist of a literary or dramatic work. In many works (other than epic poems), a person with qualities such as amazing courage or nobility, in which the usual heroic aspects are embodied, is used more as a "protogonist" neutral term for misunderstanding. Because the main character cannot be higher spiritually or otherwise. The protagonist, devoid of heroic qualities and disappointing to the reader, is used as an "antihero" [ 5.112].This term means a negative hero.

According to Russian scientists, the word "character" comes from the French word "personnage", the English word "character" - from the German word "person", "figure" and, according to narratology, this is a component event[6;90].Another Russian scholar, Lilia Chernetz, notes that modern literature uses phrases such as "literary hero" and "moving person" [8.197]instead of characters.

We must know that not all characters in the play are heroes. Let us now consider the definition given to a literary hero in a literary dictionary. A literary hero is an image of a person who occupies a leading position in the system of characters in a work and plays an important role in the formation and expression of an ideological and artistic concept.Understanding the term in this sense implies the categorization of the characters of an epic or dramatic work: plot events are organized around the main character, and other characters are included in the reality of the work in relation to him; they are in an integrative relationship with the main character (subordinate ruler) and perform auxiliary functions in relation to him.In large-scale works with a complex multiline plot structure, you can move not one, but several characters. In this case, the character system is divided into microsystems, in the center of which is one of the heroes[10.378].Apparently, not every character in the play is a literary hero.

The change of literary eras is always marked by the change of the literary hero. Themes, problems, ideas, motives, plots can, varying, pass from century to century: love, good and evil, fathers and children, superfluous people, power and people and many others. etc. But the literature of each new time, changing along with the historical epoch, sensitively reacting to the changes taking place in life, changing synthesizing / forming new forms, genres, means, methods, rhythms, declares itself at a new stage of its development by changing, first of all, the literary protagonist. And it has always been that way.Simplified, this is expressed in the following: Greco-Roman antique literature showed us a mythologized hero who is in harmony with the world in which fate dominates; the middle ages depicts the hero of the sufferer, comprehending the world through God; Renaissance literature creates the image of a conquering humanist; exalted hero of the baroque; a man of duty in the era of classicism; a reasonable, philosophizing hero of educational realism; aesthetic sentimentalism; suffering, in eternal discord with the world and with himself, a romantic hero; in a moral search, the imperfect hero of critical realism; complex, multifaceted, - a changeable hero of modernity; fighter for the new world hero of socialist realism. That is, at all times, relatively speaking, novels are written, poems are composed, and it is the hero who becomes the sign of the change in literary time.

\section{METHODS}

When the work of art tells the story of the life of a nation, it is natural that it expresses the spirit, traditions, and national symbols of this nation $[1 ; 86]$.From the names of the heroes to their costumes, spiritual experiences, customs - the image of nature in all this is impossible without 
the writer's national psyche that has absorbed it.

Ummat Toychiev explains: "It is not a sin for a national writer to write in a language different from the life of another nation, but even in this case he cannot completely abandon the national feeling and national spirit in his work.Without nationalism, without interethnic affiliation, literature is spiritually and formally impoverished"[15.454]. The main reason for this is that his national qualities are rooted in his blood.If a writer firmly stands on the national position of the people to which he belongs, if he can look at the events described from the point of view of the foremost child of his people and look into the future, the national feelings expressed in his work will acquire a universal character.Such qualities of literature are reflected in the reader, first of all, in the image of the hero, in his actions, in his actions, in his manners, in his morality and sees in manners. All of our works praising our nationality are a vivid example of this[2.87].Comparative, historical and analytical methods have been used in this article.

In modern theoretical literary criticism, there is still no terminological unity regarding the designation of the hero. For example, Russian scolar V. Khalizev in his work "Theory of Literature" uses a synonymous series at once to designate a hero: a character, an acting person, a literary hero. ${ }^{1}$ We will focus on the term hero / literary a hero who, in our opinion, more fully expresses the carrier of consciousness and the subject of the image in the text. The term literary hero was also used by L. Ya.Ginzburg, who understood by a literary hero a complete character of a work with a full being. ${ }^{2}$ The hero of each literary era is created according to a "given formula" (L. Ginzburg's term), he is recognizable and he acts as a carrier

\footnotetext{
${ }^{1}$ Хализев В. Е. Теория литературы. - М., 2000.

- С. 159-160.

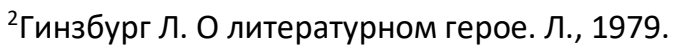

certain system of traits, qualities. As a carrier of consciousness and at the same time - the subject of the image, the hero stands between the reader and the world portrayed by the author, realizing the author's intention and conveying this idea to the recipient. In large literature, the hero is not projected onto the personality of the author, moreover, interpretations of the hero, sometimes directly opposite, are permissible.

\section{RESULTS}

Walter Scott holds a special place in the history of XIXth century English literature. His historical works on the rise of English romanticism mark the early stages of the transition from romanticism to realism. Scott created a fundamentally new genre variety of the novel - the historical novel. However, in his innovation, the writer relied on time-honored literary traditions. In his portrayal of the historical past, Scott was guided by Shakespeare's experience. As he knew, Shakespeare was an author who introduced his compatriots to national history and set an example for all subsequent generations of writers who create works on historical subjects. Shakespeare's historical dramas are an unrivaled combination of life's truth and fiction, achieved through the transforming power of creative imagination.Scott was fascinated by the lack of author's assessments in the plays of the great playwright, the secret of success of which was largely based on the desire to portray other people, to create lively, convincing characters, and not to impose their own point of view on what was happening to readers or viewers. Shakespeare is above all an objective chronicler who captures portraits of the past for the future. In the preface to Peveril Peak (1823), Scott says bluntly that his compatriots know best of all those episodes of national history that were depicted by Shakespeare. Already in his first novel "Waverley; or Tis sixty years since" (1814) in which the author has been working since 1805. Scott, 
following Shakespeare, focuses primarily on the characters and passions of his heroes, striving for that ideal naturalness that is inherent in the characters Shakespeare's Chronicles.[18]We know that historical novel is a type of novel in which the main characters, plot and setting are based on historical persons, events or places. Walter Scott's Ivanhoe (1819) and Charles Dickens' A Tale of Two Cities (1859) are major examples of it.Although Scott's novels are adventure novels and not only historical, acquaintance with them leads to many reflections. Each novel provides a variety of lessons. If we speak about Scott's first historical novel, "Waverley", which brought fame to the writer.

The XVII-XVIII centuries Great Britain is a country with numerous contradictions: between the Scots and the British, supporters of the Stuarts and the Hanoverian dynasty, between royalists and republicans, between Catholics and Protestants, between various currents within Protestantism itself. During the time of Walter Scott, not all of these contradictions subsided. The ancestors participated in those events, occupied certain positions.

Walter Scott likes to emphasize in his novels the noble attitude of the main characters to each other, depicting negative characters. If we speak about the novel "Count Robert of Paris", in which the meeting of two opponents the Byzantine mercenary Hereward (from the Anglo-Saxons) and the knight Robert - ends in friendship. The meeting of different cultures, worldviews (and not only peace-loving ones) is given a lot of attention in the novels of Walter Scott. We see how the British and Scots, Byzantines and Crusaders, Christians and Muslims, Scots and Burgundians interact with each other ... The British at that time had an idea of the Scots as "wild highlanders". These were the novels of Walter Scott that changed this opinion. In his novels "Waverly", "Rob
Roy" and others, the writer shows that the British and the Scots are no worse or better than each other, but people of different cultures.

However, not only Anglo-Scottish relations in the XVIII century, the history of Scotland in general, but also the Middle Ages came under close scrutiny by Walter Scott. As a rule, since the Renaissance, the Middle Ages were depicted in dark colors. Walter Scott was one of the first to revise this assessment, showing that one cannot look at that era in one dimension. Although, we repeat, considering any event, any historical period, the writer tries to be objective.

The Uzbek novel played an important role not only in artistic and aesthetic development, but also in the socio-political growth of the Uzbek people. The immortality of the novel of socialist realism lies in its inseparable connection with life, in its ability to reflect the deep processes of time. Using the example of the experience of the development of the Uzbek novel, the author refutes the existing theories about the "death", "crisis" of the novel genre.The life of a person and his struggle for his ideals, starting with Navoi, became the object of artistic depiction of literature. This explains the emergence of one of the factors that contributed to the birth of the novel.The portrayal of the common person as an equal member of society, albeit in an idealized sense, was of great importance in the initial stage of the development of literature. Another major feature of Navoi's epic poems, which contributed to the birth of the prose novel, was the great poet's desire to reveal the inner world of his heroes, the psychological reliability of their characters and actions. The Uzbek novel, born on the October Revolution, it has already a history worthy of deep study. Its best examples were included in the gold fund of Soviet and world novelism. The scientific generalization of the rich experience of the literary practice of masters of the Uzbek novel became one of 
the primary tasks of Uzbek Soviet literary criticism.

We know Behbudi, Fitrat, Cholpon, Abdulla Qodiri, Abdulla Avloni, Munavvarqori, FayzulloKhojayev, Sofizoda, Tavallo, IshaqjonIbrat, among others, were among the brightest representatives of Jadidism. those who tried. They have done a great job in uplifting the nation and preventing its dignity from being tarnished[ 1].AbdullaKadiri was instrumental in creating a realistic novel in the Uzbek Soviet literature. He is the representative of jaded movement in Turkistan. Until recently, his work remained in the shadows, thus a whole period of our literature remained unexplored, which prevented a full coverage of the historical path of the Uzbek realistic novel. As you know, there were contradictory moments in A. Kadiri's work. However, for us, in this case, it is not its shortcomings that are important, but the fact that $\mathrm{K}$ adyri introduced something new into our literature. Abdulla Kadiri'snovel " Bygone days" is the first Uzbek historical and realistic novel. Although Abdulla Kadiri lived a short life, he left the huge, weighty, important spiritual-enlightenment, artistic legacy of aesthetic significance. He was at the same time a poet, publicist, storyteller, comedian, playwright, most importantly, great and a unique novelist in creating the first historical novel.

Kadiri's novels "Bygone Days" and "Scorpion from the Altar" were the first positive results of his search in creating an Uzbek realistic novel. In the process of working on the novel " Bygone Days " A. Kadiri had to overcome extreme difficulties, which were aggravated, in addition to the inexperience of the young prose writer, by the absence of established traditions in the field of novelism in Uzbek literature. Nevertheless, we can safely say that with Kadiriy's novels the history of Uzbek literature and the formation of this genre began. A. Kadiri with his novels marked the beginning of a new stage in the history of Uzbek literature. The novel "Bygone Days" is the first modern realistic novel in Uzbek literature. Its content covers one of the important periods in the history of the Uzbek people - the collapse, which began the decline of the Khanate in Central Asia in the middle of the last century. The theme of family happiness runs through the novel as a central line: however, the contradictions that have arisen on the path of the heroes to this happiness, the struggle for love, are subject to the disclosure of the class essence of the social system, that era, and its negative sides. The love between Otabek and Kumishbibi and its subsequent downfall are associated and intertwined with historical events - the struggle between the Kokand Khanate and the ruler of Tashkent, with the war for the throne, which was flaring up at that time. However, the heroes of the novel, who oppose the injustice of the Khanoz, Beks and other exploiters, do not fully understand the necessity of the existing social system.

In the novel "Bygone days " A. Kadiriy expressed his views on the family and social life of pre-revolutionary Turkestan, painted vivid realistic images of the main characters of the novel - Otabek and Yusufbek, typical representatives of the progressive people of Uzbek society in the first half of the XIXth century. A multidimensional narrative, the presence of side plot moves, a consistent and everincreasing development of events, characterizes the novel "Bygone Days". Despite the well-known ideological mistakes, explained by the limited worldview of the writer, who took the first steps towards mastering the method of socialist realism, the novel "Days Gone" carries a certain social charge.In the novel, A. KadiriOtabek also leaves his home, but on his way he encounters real life, real people, cruelty and injustice.To the question "What is the main thing in a historical novel?" the Uzbek writer Oybekreplied that for a historical novel there is no need for a genuine historical 
personality - it is enough that a person who has "come out" from the people acts in it. " He needs a man based on human truth, having a rich dream and a complex character, regardless of whether he is Peter or Fedka. The people are the creator of history only because they consist of such real people [14]. Here the writer reveals two essential aspects of the issue. First, he points out that there is not a single historical novel that does not depict the activities of a person who has emerged from the people; secondly, historical novels do not require historical figures. Later, the well-known orientalist academician E. Bertels wrote: "The novels of Abdulla Qadiri, with all their system, with all their original style are Uzbek novels. There are five schools of the novel: French, Russian, English, German and Indian. Now Abdullah Kadiri created the sixth, namely the Uzbek, school of the novel. "

\section{CONCLUSION}

At the heart of Scott's novels events involve significant socio-historical contradictions. The themes in Walter Scott's works are always important, and no matter what period they are written about, today's reader will understand. Each of Scott's novels serves to reveal to the reader a whole world of important historical events and great human emotions. In general, his novels are of great importance in covering the events of the period of British and Scottish life from the end of the twelfth century to the beginning of the nineteenth century.For the Scotish people, Walter Scott is not just a writer. He revived the historical memory of this nation and discovered Scotland all over the world, first and foremost in England. Before his work was published, almost no one in Scotland was interested in Scottish history, considering the Scots to be "savages" in England, especially in its capital London. . In Scott's works, the events take place mainly during the AngloScottish wars. In these wars, the "wild" but sincere and very powerful mountaineersthe Scots clashed with the British, who were considered "civilized".

Walter Scott is a very adept at depicting many popular historical scenes. As in his other novels, in "Ivanhoe" the writer combines the depiction of personal destinies with historical events, vividly depicting amazing adventures and real historical events. In the Middle Ages, the character traits, deeds and ideas of people far from readers in England were embodied in life with great artistic skill. This work by Walter Scott helps to study, understand and feel many historical events. The novel "Bygone Days" is the peak of Abdulla Qadiri's creative rise and a remarkable milestone in the development of Uzbek prose.A writer with great artistic skill, truthfully illuminates the contradictory world of feudal reality. The people, as the creator of material and cultural values, acts, on the one hand, as the guardian and protector of statehood, on the other, they undermine the foundations of the khanate, rebel against the oppressors. And specifically against the rulers who imposed exorbitant taxes on the people.

Two founders of historical novels of different countries left the great heritage to us. Their novels give us much information about the national history of England and Uzbekistan and always teach us to remember it.

\section{References}

1. Umarova M.The role of jadid representatives in world literature. Journal of Critical reviews. Vol 7,Issue 17 2020.p2190

2. Baboev.T.Fundamentals of Literary Studies.Tashkent: Uzbekistan, 2002.- p 51. 3. Belinskiy V.G. Complete works. V.5. - Moscow: AN SSSR, 1954, p. 234.

4. Boltaboev $\mathrm{H}$, Mahmudov $\mathrm{M}$. History of literary-aesthetic thinking. T: Classical word, 2016,2 vol. -p.23 
5. Chris Baldick. The Concise Oxford Dictionary of Literary Terms. New York Oxford University Press. -p.112

6. Encyclopedic reference book "Contemporary foreign literary criticism". Moscow: Intrada, 1999.-c 90

7. Ginzburg L. About the literary hero. Leningrad: Soviet writer, 1979.-p 89

8. Introduction to literature:Tutorial/ Under red.L.Chernets.-Moskow:

Grad.School., 2004.-p.197

9. Kadiriy A. The difficulty of creativity. Tashkent: Teacher 1995.-p.12

10. Kuronov D, Mamajonov Z, Sheralieva M. Dictionary of Literary Studies. T: Akadpublication, 2010.-p.378

11. Kushjonov.M. Life and skill. Tashkent: Uzliterature publication , 1962, pp. 12-16

12. Khudoiberdiev E. Introduction to literary criticism. Tashkent: East, 2008. p. 40

19.
13. Khudoiberdiev E. Introduction to Literary Studies. Tashkent: Teacher, 1995.-p. 250

14. Oybek. A literature, history, modernity, "Culture of Uzbekistan", 1966, October 1

15. Toychiev U. Criteria of art in Uzbek literature and their rhythms. T: New generation, 2011.-p.454

16. William H. Gass. The Concept of Character in Fiction. [El. resource] / Mode available URL: https: // sahityaparikrama. weebly.com/ uploads/1/2/0/9/ 120943912/the_concept__of_character _in_fiction_william_gass.pdf

17. http://e-

adabiyot.uz/adabiyotshunoslik/tanqidchilik /1278-maqola.html

18. http://19v-euro-lit.niv.ru/19v-eurolit/articles-eng/sidorchenko-valterskott.htm 